\title{
Structural elucidation of some antimicrobial constituents from the leaf latex of Aloe trigonantha L.C. Leach
}

\author{
Mekdes Megeressa', Daniel Bisrat', Avijit Mazumder ${ }^{2}$ and Kaleab Asres ${ }^{1 *}$
}

\begin{abstract}
Background: The incidents of drug resistant microorganisms and the need of treatments for newly emerging pathogens are of great concern to the global community. Our ability to treat infectious diseases is dependent on the development of new pharmaceuticals, and one potential source being medicinal plants with traditional claims. The leaves of Aloe trigonantha L.C. Leach, an endemic Ethiopian plant, are locally used for the treatment of infectious and inflammatory diseases. This study explores the potential of the latex of this plant and compounds isolated thereof for their in vitro antibacterial and antifungal properties.
\end{abstract}

Methods: Analytical RP-HPLC and silica gel preparative TLC were used for identification and isolation of active constituents, respectively. Characterization of the compounds was based on UV, IR, HR-ESIMS, ${ }^{1} \mathrm{H}$ and ${ }^{13} \mathrm{C}$ NMR, and 2D-NMR spectral assignments. Antimicrobial activity studies were carried out against 21 pathogenic bacterial and 4 fungal strains using the disk diffusion method. Minimum inhibitory concentrations (MICs) were determined by the broth dilution method.

Results: A C-glycosylated chromone identified as aloesin, and three C-glycosylated anthrones characterized as 8-Omethy-7-hydroxyaloin A/B, aloin A/B and aloin-6'-O-acetate $A / B$ were isolated. The latex and isolated compounds exhibited in vitro antibacterial activity against the tested pathogens. In some cases the activity of the isolated compounds ( $\mathrm{MIC}=10 \mu \mathrm{g} / \mathrm{mL}$ ) was comparable with that of the standard drug ciprofloxacin, particularly against some of the Gram-negative bacterial strains tested. However, their activity towards the fungal pathogens tested was relatively weaker showing maximum activity against Candida albicans with MIC value of $400 \mu \mathrm{g} / \mathrm{mL}$.

Conclusion: The present findings can be used for further research aimed at the development of new antibacterial agents, and may also justify the ethnomedicinal claim of the plant for the treatment of infectious diseases.

Keywords: Aloe trigonantha, Antimicrobial activity, 8-O-methy-7-hydroxyaloin A/B, Aloesin, Aloin A/B, Aloin-6'-Oacetate $A / B$, Disk diffusion

\section{Background}

Microbial diseases are among the major causes of morbidity and mortality in the world, and particularly in developing countries [1,2]. Regardless of the extensive works done towards the control of microorganisms, incidents of drug resistant microorganisms, reduction in new antimicrobials in pharmaceutical pipeline and the need of treatments for newly emerging pathogens pose

\footnotetext{
* Correspondence: kaleab.asres@aau.edu.et

'Department of Pharmaceutical Chemistry and Pharmacognosy, School of pharmacy, College of Health Sciences, Addis Ababa University, Addis Ababa, Ethiopia

Full list of author information is available at the end of the article
}

an enormous threat to public health [3]. A report compiled by WHO indicates that devoid of urgent and coordinated action, the world is heading towards a post-antibiotic era in which common infections and minor injuries, which have been treatable for decades, can once again kill [4]. These negative health trends have driven a global initiative towards the search for new sources of antimicrobial substances mainly from medicinal plants. Medicinal plants represent rich sources of antimicrobials with higher activity and reduced side effects. It is, therefore, suggested to carry out an intense screening of these plants in order to

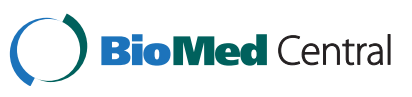

(C) 2015 Megeressa et al. Open Access This article is distributed under the terms of the Creative Commons Attribution 4.0 International License (http://creativecommons.org/licenses/by/4.0/), which permits unrestricted use, distribution, and reproduction in any medium, provided you give appropriate credit to the original author(s) and the source, provide a link to the Creative Commons license, and indicate if changes were made. The Creative Commons Public Domain Dedication waiver (http://creativecommons.org/publicdomain/zero/1.0/) applies to the data made available in this article, unless otherwise stated. 
validate their use in folk medicine and isolate the active principle(s) [5-7].

The genus Aloe is represented by 600 species and belongs to the family of Asphodelaceae [8,9]. Aloe plants are native to sub-Saharan Africa, many islands of western Indian Ocean, including Madagascar and Saudi Arabian Peninsula. In Ethiopia and Eritrea, about 46 species of Aloe have been described so far with a high proportion of endemics adapted to harsh climates [10]. It has been reported that the leaf latex of several Aloe species and their constituents possess wide spectrum of biological activities, such as antimicrobial [11, 12], antimalarial [13], and antiglycation [14].

Aloe trigonantha L.C. Leach, locally called 'Eret', is among the endemic Aloe species of Ethiopia, which has been described in 1971 in an area between the cities of Bahir Dar and Gonder in the northern part of the country. Like many other Aloe species found in Ethiopia with ethnomedicinal applications $[15,16]$, the local people extensively use the leaves of $A$. trigonantha for the treatment of infectious and inflammatory diseases [17]. However, despite its use in traditional medicine and possible therapeutic applications, no phytochemical or biological studies carried out on the plant could be found in the literature. The purpose of this study is, therefore, to test the latex against a panel of microbes to characterize its antimicrobial effect. The report further details the extraction, isolation, identification and structural elucidation of the antimicrobial compounds of the latex.

\section{Methods}

Plant material

The latex of $A$. trigonantha was collected in January 2011 from Kutkuatema, a small village 568 km northwest of Addis Ababa, Ethiopia. The plant was authenticated by Professor Sebsebe Demissew, the National Herbarium, Department of Biology (DoB), Addis Ababa University (AAU) where voucher specimen was deposited with collection number MD 001.

\section{Bacterial strains}

In vitro antibacterial assays were carried out against the following Gram-positive bacterial strains: Bacillus pumilus 82, B. subtilis ATCC 6633 and Staphylococcus aureus ML 267. The Gram-negative bacterial strains used were: Escherichia coli $3: 37$ C, E. coli 7360 , E. coli 872 , E. coli CD/99/1, E. coli $\mathrm{K} 88$, E. coli $\mathrm{T}$ 37, E. coli ROW 7/12, E. coli 5933, Salmonella enterica TD 01, S. typhi Ty2, Shigella boydii D13629, S. dysentery 8, S. flexneri Type 6, $S$. soneii 1, Vibrio cholerae NCTC 5596, V. cholerae NCTC 10732, V. cholerae NCTC 11501, and V. cholerae NCTC 4693. All the bacterial strains were procured from the Department of Technology, Jadavpur University; Central Drugs Laboratory, Kolkata and Institute of
Microbial Technology, Chandigarh, India. The purity of the strains was checked according to the standard microbiological, cultural and biochemical tests prior to sensitivity tests against the test samples.

\section{Fungal strains}

Antifungal activity testing was carried out on the following fungal pathogens: Aspargillus niger ATCC 6275, Candida albicans ATCC 10231, Penicillium funiclosum NCTC 287and P. notatum ATCC 11625. All the fungal strains were procured from Central Drugs Laboratory, Kolkata, India.

\section{Instrumental analysis}

UV spectra were recorded on a Shimadzu Spectrophotometer MultiSpec-1501 (200-400 nm) at room temp. IR spectra were carried out in $\mathrm{KBr}$ plates on a Perkin-Elmer BX (400-4000 $\mathrm{cm}^{-1}$ ) instrument. HPLC was performed using an UltiMate 3000 Standard HPLC Systems equipped with a UV photodiode array detector (190-400 nm). ESI-MS were recorded on an Ultimate 3000 LC-MS with negative mode. The source voltage and temperature were fixed at $3 \mathrm{kV}$ and $250{ }^{\circ} \mathrm{C}$. NMR spectra were recorded on a Bruker Avance DMX400 FT-NMR spectrometer operating at $400 \mathrm{MHz}$ for ${ }^{1} \mathrm{H}$ and $100 \mathrm{MHz}$ for ${ }^{13} \mathrm{C}$ at room temperature. Signals were referred to an internal standard TMS. Chemical shifts were reported in $\delta$ units and coupling constants $(J)$ in $\mathrm{Hz}$.

\section{Extraction of the latex}

The leaf latex of $A$. trigonantha was collected by cutting the leaves transversally near the base and arranging them concentrically around a plate. The latex was then left in open air for three days to allow evaporation of water, which yielded a dark brown powder.

\section{HPLC operating conditions}

HPLC was performed using a Phenomenex IB-Sil C-18 reversed phase column $(250 \mathrm{~mm} \times 3.2 \mathrm{~mm}, 5 \mu \mathrm{m}$ diameter particles); flow rate $1 \mathrm{~mL} / \mathrm{min}$. The solvent system consists of $30 \%$ to $60 \%$ linear gradient of methanol in water over $25 \mathrm{~min}, 3 \mathrm{~min}$ isocratic, $100 \%$ in $2 \mathrm{~min}, 4 \mathrm{~min}$ isocratic. UV absorption spectra were recorded at $254 \mathrm{~nm}$.

\section{Isolation of compounds}

The latex was dissolved in methanol and applied directly to preparative thin layer chromatography (PTLC) plates over silica gel G6 $\mathrm{F}_{254}$ (Merck; $20 \mathrm{~cm} \times 20 \mathrm{~cm}$; $0.50 \mathrm{~mm}$ thickness). A solvent system of EtOAc/ $\mathrm{MeOH} / \mathrm{H}_{2} \mathrm{O}$ (77:13:10) was used for isolation. PTLC plates with $0.25 \mathrm{~mm}$ thickness were used to further purify the compounds. Chromatographic zones were visualized first in daylight and then under ultraviolet light of wavelengths 254 and $366 \mathrm{~nm}$. The bands were 
scraped off, washed with EtOAc/MeOH (1:1) and filtered to yield four compounds (1-4).

\begin{abstract}
Aloesin (1): A pale yellow amorphous solid; $6.8 \%(\mathrm{w} / \mathrm{w})$; HPLC: $t_{R}=11.70 \mathrm{~min}$; TLC: $R_{f}=0.32(\mathrm{EtOAc} / \mathrm{MeOH} /$ $\left.\mathrm{H}_{2} \mathrm{O}-77: 13: 10\right)$; UV $\lambda_{\max }(\mathrm{MeOH}): 215,244,253,295 \mathrm{~nm}$; IR $v_{\mathrm{cm}-1}$ : 3436, 2923, 1684, 1384. LRESI-MS (-ve mode) $\mathrm{m} / \mathrm{z}: 393[\mathrm{M}-\mathrm{H}]^{-}$, indicating a molecular formula of $\mathrm{C}_{19} \mathrm{H}_{22} \mathrm{O}_{9} .{ }^{1} \mathrm{H}$ NMR (DMSO) $\delta: 2.25$ (3H, $s, 11-\mathrm{CH}_{3}$ ), $2.62\left(1 \mathrm{H}, s, 5-\mathrm{CH}_{3}\right), 3.15-3.70\left(5 \mathrm{H}, m, \mathrm{H}-2^{\prime}-\mathrm{H}^{-} 6^{\prime}\right), 3.21$ (1H, s, H-9), $4.70\left(1 \mathrm{H}, b r s, \mathrm{H}^{\prime}-1\right), 6.12(1 \mathrm{H}, s, \mathrm{H}-3), 6.69$ (1H, s, H-6). ${ }^{13} \mathrm{C}$ NMR (DMSO): $23.06\left(5-\mathrm{CH}_{3}\right), 30.26$ (11- $\left.\mathrm{CH}_{3}\right), 47.97\left(9-\mathrm{CH}_{2}\right), 61.80\left(\mathrm{C}-6^{\prime}\right), 73.88\left(\mathrm{C}-1^{\prime}\right), 70.83$ (C-4'), 71.10 (C-2'), 79.02 (C-2'), $81.56\left(\mathrm{C}-5^{\prime}\right), 110.88$ (C-8), 112.48 (C-3), 114.27 (C-4a), 117.97 (C-6), 147.84 (C-1a), 160.65 (C-7), 163.66 (C-2), 179.47 (C-4), 140.48 (C-5), 203.82 (C-10).
\end{abstract}

8-O-Methyl-7-hydroxyaloin A/B (2): A brown amorphous solid; $12.5 \%(\mathrm{w} / \mathrm{w})$; HPLC: $t_{R}=16.87 \mathrm{~min}$; TLC: $R_{f}=0.35\left(\mathrm{EtOAc} / \mathrm{MeOH} / \mathrm{H}_{2} \mathrm{O}-77: 13: 10\right) ; \mathrm{UV} \lambda_{\max }$ (MeOH): 199, 222, 294, $348 \mathrm{~nm}$; IRv $v_{\mathrm{cm}-1}: 3411,2853$, 1636. HRESI-MS (+ve mode) $\mathrm{m} / z: 471.12640[\mathrm{M}+\mathrm{Na}]^{+}$, (calcd. for $\left.\mathrm{C}_{22} \mathrm{H}_{24} \mathrm{O}_{10} 471.12617[\mathrm{M}+\mathrm{Na}]^{+}\right)^{1} \mathrm{H}$ NMR

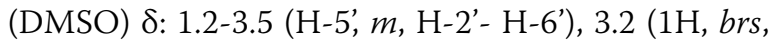
$\left.\mathrm{H}-1^{\prime}\right), 3.81\left(3 \mathrm{H}, s, 8-\mathrm{OCH}_{3}\right), 4.43(1 \mathrm{H}, d, \mathrm{H}-10), 4.48$ $(1 \mathrm{H}$, brs, $\mathrm{H}-2), 6.75(1 \mathrm{H}$, brs, $\mathrm{H}-2), 6.78(1 \mathrm{H}$, brs, $\mathrm{H}-4)$, $7.05(1 \mathrm{H}, d, \mathrm{H}-6), 7.14(1 \mathrm{H}, d, \mathrm{H}-5), 8.41(1 \mathrm{H}, s, 7-\mathrm{OH})$, $12.16(1 \mathrm{H}, s, 1-\mathrm{OH}) .{ }^{13} \mathrm{C}$ NMR (DMSO) $\delta: 44.10(\mathrm{C}-10)$, $61.40\left(8-\mathrm{OCH}_{3}\right), 62.10\left(\mathrm{C}-6{ }^{\prime}\right), 62.90\left(3-\mathrm{OCH}_{2}\right), 70.90$ (C-2'), 72.60 (C-4'), 78.40 (C-1'), 80.80 (C-3'), 84.20 (C-5), 115.80 (C-4), 117.60 (C-5), 118.45 (C-8a), 120.80 (C-2), 125.30 (C-6), 127.90 (C-1a), 131.90 (C-4a), 140.86 (C-5a), 145.30 (C-7), 147.00 (C-8), 150.50 (C-3), 160.50 (C-1), 190.20 (C-9).

Aloin A/B (3): A pale yellow amorphous powder; $15.7 \%(\mathrm{w} / \mathrm{w})$; HPLC: $t_{R}=22.19 \mathrm{~min}$; TLC: $R_{f}=0.39$ (EtOAc/MeOH/ $\left.\mathrm{H}_{2} \mathrm{O}-77: 13: 10\right) ; \mathrm{UV} \lambda_{\max }(\mathrm{MeOH})$ : 208, 299, $357 \mathrm{~nm}$; IR $v_{\mathrm{cm}-1}: 3447,1631,1618$; LRESIMS (-ve mode) $m / z: 417[\mathrm{M}-\mathrm{H}]^{-}$, indicating a relative molecular weight $\left(M_{r}\right)$ of $418\left(\mathrm{C}_{21} \mathrm{H}_{22} \mathrm{O}_{9}\right) ;{ }^{1} \mathrm{H}$ and ${ }^{13} \mathrm{C}$ NMR chemical shift of compound 3 were in a good agreement with those reported for the same compound $[11,12]$.

Aloin-6'-O-acetate A/B (4): A pale yellow amorphous solid; $18.4 \%(\mathrm{w} / \mathrm{w})$; HPLC: $t_{R}=23.87 \mathrm{~min}$; TLC: $R_{f}=$ 0.63 (EtOAc/MeOH/ $\left.\mathrm{H}_{2} \mathrm{O}-77: 13: 10\right)$ ) UV: $\lambda_{\max }(\mathrm{MeOH})$ : 200, 269, 293 and $359 \mathrm{~nm}$; IR $v_{\mathrm{cm}-1}$ : 3400, 2922, 1719, 1603, 1451 and 1383. HRESI-MS (+ve mode) $\mathrm{m} / \mathrm{z}$ : 483.12624 $[\mathrm{M}+\mathrm{Na}]^{+}$, (calcd. for $\mathrm{C}_{23} \mathrm{H}_{24} \mathrm{O}_{10} 483.12617$ $\left.[\mathrm{M}+\mathrm{Na}]{ }^{+}\right) .{ }^{1} \mathrm{H}$ NMR (DMSO) $\delta: 1.2-3.7\left(5 \mathrm{H}, m, \mathrm{H}-2^{\prime}-\right.$ $\left.\mathrm{H}-6^{\prime}\right), 2.1\left(3 \mathrm{H}, s, \mathrm{COCH}_{3}\right), 3.21\left(1 \mathrm{H}, d d, \mathrm{H}-1^{\prime}\right), 4.59$ $\left(2 \mathrm{H}, d, 11-\mathrm{CH}_{2}\right), 4.83(1 \mathrm{H}$, brs, $\mathrm{H}-10), 6.76(1 \mathrm{H}, s, \mathrm{H}-2)$, $6.97(1 \mathrm{H}$, brs, $\mathrm{H}-7), 7.23(1 \mathrm{H}$, brs, $\mathrm{H}-4), 7.38(1 \mathrm{H}, d, \mathrm{H}-5)$, $7.43(1 \mathrm{H}, d d, \mathrm{H}-6), 11.79(1 \mathrm{H}, s, 1-\mathrm{OH}), 11.80(1 \mathrm{H}, s, 8-$ $\mathrm{OH}) .{ }^{13} \mathrm{C}$ NMR (DMSO) $\delta: 21.20$ (C-7'), 44.50 (C-10), 61.80 (C-11), 65.03 (C-6'), 70.68 (C-2'), 70.70 (C-4'), 78.60 (C-3'), 81.30 (C-5'), 85.4 (C-1'), 114.20 (C-2), 115.00 (C-1a), 115.90 (C-7), 117.80 (C-8a), 119.20 (C-4), 120.70 (C-5), 136.80 (C-6), 142.30 (C-4a), 144.7 (C-5a), 150.50 (C-3), 161.20 (C-1), 161.30 (C-8), 170.80 (C-8'), 193.75 (C-9).

\section{In vitro antibacterial activity test}

In vitro antibacterial assay was screened by the disc diffusion method as described by Mitchell and Carter [18], by determining zones of inhibition produced by the test samples and comparing them with those of ciprofloxacin. A stock solution of the latex and various isolated compounds was prepared in $1 \%$ DMSO $(1 \mathrm{mg} / \mathrm{ml})$ for the antibacterial activity tests and $10 \mathrm{mg} / \mathrm{ml}$ for the antifungal activity tests. Concentrations ranging from 5 to $800 \mu \mathrm{g} / \mathrm{mL}$ for antibacterial activity tests, and 50 to $2000 \mu \mathrm{g} / \mathrm{mL}$ for antifungal activity tests were employed by diluting the stock solution in appropriate volumes of water. Serial nutrient agar plates were then prepared by pouring of molten media into sterile Petri dishes and incubated at $37^{\circ} \mathrm{C}$ for $24 \mathrm{~h}$ to check for any sort of contamination. The inoculums were then swabbed uniformly and allowed to dry for $5 \mathrm{~min}$. Then, the filter paper discs (Whatman no. 1) of $6 \mathrm{~mm}$ were impregnated with the test samples and placed on the surface of the medium. The Petri dishes were then incubated at $37{ }^{\circ} \mathrm{C}$ for $24 \mathrm{~h}$ and the diameter of zone of inhibition was measured in $\mathrm{mm}$. Similar procedure was adopted for ciprofloxacin and the corresponding zone of inhibition was compared accordingly. $1 \%$ DMSO was used as a negative control.

\section{In vitro antifungal activity test}

The antifungal potential of the test samples $(2000 \mu \mathrm{g} / \mathrm{mL})$ was screened by disc diffusion method (as described for the determination of antibacterial activity) against the fungal pathogens on Saborauds dextrose media. The Petri dishes were incubated at room temperature for 3 days and the diameter of zone of inhibition was measured in $\mathrm{mm}$. Griseofulvin was used as a reference standard.

Determination of minimum inhibitory concentrations (MICs) The MICs of the latex and isolated compounds were determined by the broth dilution method, as described by Hecht et al. [19]. Nutrient agar and Saborauds dextrose agar were used for bacterial and fungal growth, respectively. Concentrations ranging from 5 to $800 \mu \mathrm{g} / \mathrm{mL}$ for antibacterial activity tests, and 50 to $2000 \mu \mathrm{g} / \mathrm{mL}$ for antifungal activity tests were employed by dissolving the test samples in DMSO. A sterility control was also carried out 
(growth control contained nutrient broth plus DMSO, without antimicrobial substances). Each test and growth control well was incubated for $24 \mathrm{~h}$ at $37{ }^{\circ} \mathrm{C}$ for bacteria and 3 days at $25^{\circ} \mathrm{C}$ for fungi.

\section{Results and discussion}

Structure elucidation

Reversed phase-HPLC analysis of the leaf latex of $A$. trigonantha revealed the presence of four major compounds (Fig. 1), identified as aloesin (1), 8-O-methy-7hydroxyaloin A/B (2) aloin A/B (3) and aloin-6'-O-acetate A/B (4) by spectroscopic techniques including ESIMS, ${ }^{1} \mathrm{H},{ }^{13} \mathrm{C}$ NMR and DEPT-135 spectral data.

Compound 1, isolated as a pale yellow amorphous solid, showed $[\mathrm{M}-\mathrm{H}]^{-}$at $m / z=393$ in the negative-mode LRESI-mass spectrum, indicating a relative molecular weight of 394. A molecular formula of $\mathrm{C}_{19} \mathrm{H}_{22} \mathrm{O}_{9}$ was deduced based on LRESI-MS, ${ }^{1} \mathrm{H}$ and ${ }^{13} \mathrm{C}$ and DEPT 135 spectral data. The presence of a chromone skeleton was deduced from the UV spectrum $\left(\lambda_{\text {max }}: 215,244,253\right.$ and $295 \mathrm{~nm})$ [20], ${ }^{1} \mathrm{H}$ and ${ }^{13} \mathrm{C}$ NMR spectral data. Hence, compound 1 was unequivocally identified as 2 -acetonyl8- $\beta$-D-glucopyranosyl-7-hydroxy-5-methylchromone, commonly known as aloesin (Fig. 2) by comparing its ${ }^{1} \mathrm{H}$ and ${ }^{13} \mathrm{C}$ NMR data with those reported for the same compound in the literature [21].

Compound 2 was isolated as a brown amorphous solid. The positive-mode HRESI-mass spectrum of compound 2 gave a pseudomolecular ion at $\mathrm{m} / z 471.12640$ $[\mathrm{M}+\mathrm{Na}]^{+}$, corresponding to a molecular formula of $\mathrm{C}_{22} \mathrm{H}_{24} \mathrm{O}_{10}$ (calcd. 471.12617). It was identified as an anthrone derivative from the UV spectrum $\left(\lambda_{\max }\right.$ : 199, 222, 294 and $348 \mathrm{~nm}),{ }^{1} \mathrm{H}$ and ${ }^{13} \mathrm{C}$ NMR spectral data [20]. The ${ }^{1} \mathrm{H}$ and ${ }^{13} \mathrm{C}$ NMR spectral data of compound 2 revealed that the signals mostly appear either in pairs or overlapping on one another further suggesting that the

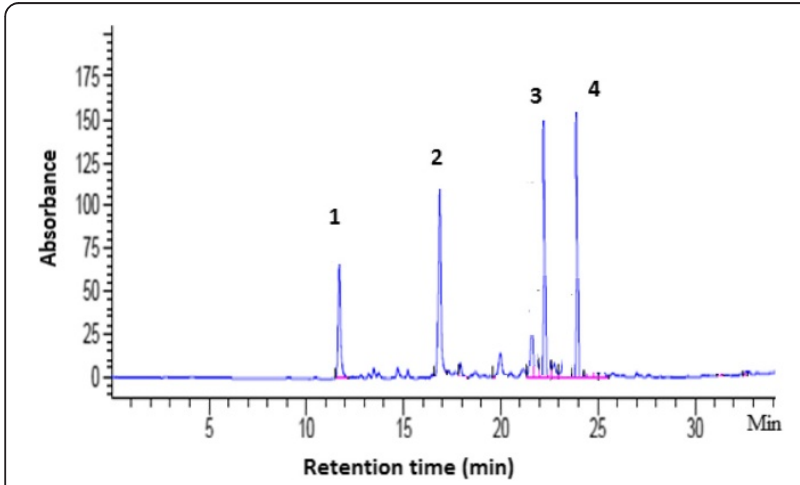

Fig. 1 HPLC chromatogram of the leaf latex of Aloe trigonantha. Column: RP-18 (250 mm x $3.2 \mathrm{~mm}, 5 \mu \mathrm{m}$ diameter particles); flow rate $1 \mathrm{~mL} / \mathrm{min}$; UV detection: $254 \mathrm{~nm}$; Solvent system: $30 \%$ to $60 \%$ linear gradient of methanol in water over $25 \mathrm{~min}, 3 \mathrm{~min}$ isocratic, $100 \%$ in 2 min, 4 min isocratic compound is a mixture of two closely related compounds. Hence, compound 2 was unambiguously characterized as the known 8-O-methyl-7-hydroxyaloin A/B (10-C- $\beta$-Dglucopyranosyl-1,7-dihydroxy-8-O-methyl-9-anthracenone) (Fig. 2) by comparing its ${ }^{1} \mathrm{H}$ and ${ }^{13} \mathrm{C}$ NMR spectra data (listed in the Method section) with those reported for the related compound, homonataloin [22].

Compound 3 was obtained as a yellow amorphous solid with a pseudomolecular ion at $m / z: 417[\mathrm{M}-\mathrm{H}]^{-}$ in negative-mode ESI-mass spectrum. A molecular formula of $\mathrm{C}_{21} \mathrm{H}_{22} \mathrm{O}_{9}$ was determined based on its ESIMS, ${ }^{1} \mathrm{H}$ and ${ }^{13} \mathrm{C}$ NMR spectral data. Thus, compound 3 was unequivocally characterized as aloin $\mathrm{A} / \mathrm{B}$, which was previously isolated from a number of Aloe species, by comparing its ${ }^{1} \mathrm{H}$ and ${ }^{13} \mathrm{C}$ NMR spectral data with those data reported in the literature for the same compound $[11,12]$.

Compound 4 was obtained as a yellow amorphous solid with the positive-mode HR-ESI mass spectrum showing a pseudomolocular ion at $m / z=483.12624[\mathrm{M}+\mathrm{Na}]^{+}$, indicating a molecular formula of $\mathrm{C}_{23} \mathrm{H}_{24} \mathrm{O}_{10}$ (calcd. 483.12617). The presence of an anthrone moiety in compound 4 was confirmed from its UV ( $\lambda_{\max }$ : 200, 269, 293 and $359 \mathrm{~nm}),{ }^{1} \mathrm{H}$ and ${ }^{13} \mathrm{C}$ NMR spectral data. A close analysis of the ${ }^{1} \mathrm{H}$ and ${ }^{13} \mathrm{C}$ NMR spectra revealed that the signals occurred in pairs, indicating that it was a mixture of two closely related compounds. Consequently, from its spectral data summarized in the Method section, and by comparing this data with those previously reported for the same compound [23], compound 4 was identified as 10C- $\beta$-D-glucopyranosyl-1,8-dihydroxy-3-hydroxymethyl-6'$O$-acetate- $9(10 \mathrm{H})$-anthracenone, otherwise known as aloin6-O-acetate A/B (Fig. 2). Literature survey indicates that aloin-6'-O-acetate A/B (4) is a rare natural product being previously isolated only once from the leaf latex of Aloe trichosantha [23].

\section{Antibacterial activity}

In the present study, the leaf latex of $A$. trigonantha was evaluated against 21 bacteria strains using the disc diffusion method. Our experiments showed that the latex possesses activity against most of the bacterial strains tested (Table 1). Whilst the Gram-negative bacteria including all the strains of E. coli and Salmonella spp were particularly susceptible to the latex, the Gram-positive rod bacteria Bacillus pumilus and B. subtilis appeared to be resistant. In vitro antibacterial activity of the leaf latex of Aloe harlana had previously been examined in our laboratory showing the strongest activity against several Gram-negative bacterial strains [11]. Similarly, Mariappan and Shanthi [24] reported the inhibition of Salmonella spp, Shigella sonie and Staphylococcus spp by the leaf latex of Aloe vera with MIC values of 12.3, 4.2 and $12.4 \mu \mathrm{g} / \mathrm{mL}$, respectively. 


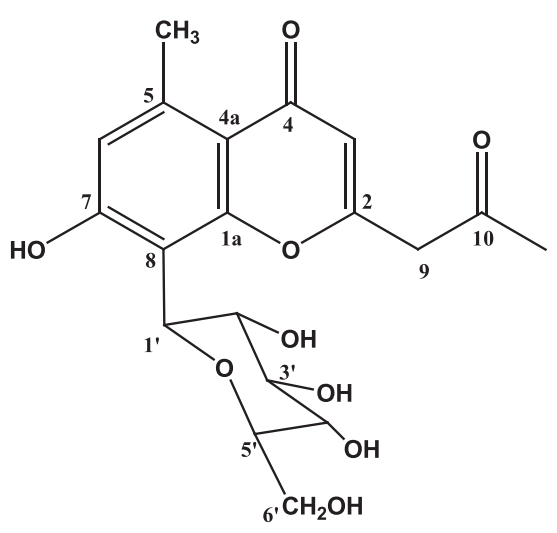

(a)

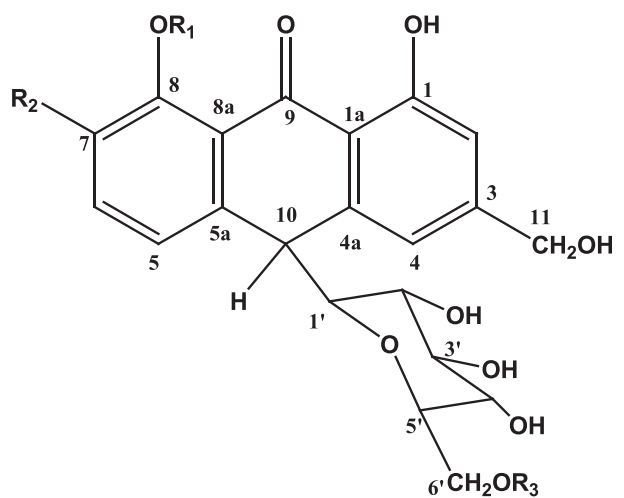

(b)

1

2: $\mathrm{R}_{1}=\mathrm{CH}_{3} ; \mathrm{R}_{2}=\mathrm{OH} ; \mathrm{R}_{3}=\mathrm{H}$

3: $\mathrm{R}_{1}=\mathrm{H} ; \quad \mathrm{R}_{2}=\mathrm{H} ; \quad \mathrm{R}_{3}=\mathrm{H}$

4: $\mathrm{R}_{1}=\mathrm{H} ; \quad \mathrm{R}_{2}=\mathrm{H} ; \quad \mathrm{R}_{3}=\mathrm{COCH}_{3}$

Fig. 2 Structures of (a) aloesin (1); (b) 8-O-methyl-7-hydroxyaloin A/B (2), aloin A/B (3) and aloin-6'-O-acetate A/B (4)

In view of the promising antimicrobial growth inhibitory effect of the latex, it was further subjected to compound isolation with the aim of finding more potent antibacterial agent(s). As shown in Table 1, the isolated compounds inhibited growth of most of the bacterial strains tested showing lower MIC values against most strains of E. coli and V. cholera than that of the latex. In particular, aloin A/B (3) showed potent action against all strains with the exception of Bacillus spp., and Salmonella enterica, which showed limited susceptibility. Aloin isolated from the latex of $A$. trigonantha also showed powerful inhibitory activity and its action was similar to aloin isolated from the latex of $A$. sinana reported in our previous work [12]. In general, the antibacterial profile of the latex was similar to those of the isolated compounds, being able to inhibit mainly the growth of Gram-negative bacteria. It appears that there was synergy among the isolated compounds as the MIC values of the latex was smaller than those of compounds 1 and 2 against Shigella soneii and Salmonella enterica, respectively. In spite of the fact that components of the latex belong to two different classes of secondary metabolites, their antibacterial activity was comparable with each other. Aloesin (1) is a chromone while the others are anthrone glycosides. Previous studies have demonstrated that natural chromones isolated from diverse plant species such as Cassia petersiana (Fabaceae) [25], Ferula communis (Apiaceae) [26] and Aloe barbadensis (Asphodelaceae) [27] as well as synthetic phosphonic derivatives of chromones [28] have activity towards Gram-negative and Gram-positive bacteria. Similarly, anthraquinones which are structurally related to anthrones have been shown to inhibit growth of several pathogenic microorganisms [29, 30].
The mechanism of action by which chromones and anthrones exert their antibacterial action is not well studied. Whilst Hamman [31] proposed that the antibacterial activity of anthraquinones isolated from the latex of $A$. vera is through mediation of solute transport inhibition in membranes, Ubbink-Kok et al. [32] reported that emodin and emodin anthrone are active against $E$. coli by inhibiting respiration-driven transport within membranes. Similar mechanisms of action could be proposed for 8-O-methyl-7-hydroxyaloin A/B (2), aloin A/B (3) and aloin-6'-O-acetate A/B (4) owing to their structural similarity to anthraquinones. However, further studies are needed to establish the actual mechanism(s) of action for these classes of compounds.

Among the bacterial strains tested, only the Grampositive bacilli bacteria were found to be resistant to the latex and its components. Similarly, the single Grampositive strain of $S$. aureus tested in the present study was shown to have a limited susceptibility to both the latex and its components. It is interesting to note that nearly all the Gram-negative pathogens tested were susceptible to both the latex and isolated compounds although they have phospholipid membrane carrying the structural lipopolysaccharide component that makes their cell wall impermeable to antimicrobial substances. This situation can be explained in terms of the chemical nature of the test samples, which could have an effect on the permeability and integrity of the bacterial cell wall. According to Alves et al. [33], the anthraquinones emodin and barbaloin affect the phospholipid membranes of bacterial cell wall resulting in remarkable changes in membrane physical properties including changes of the lipid/water interface in negatively charged 
Table 1 Zones of inhibition and minimum inhibitory concentrations (MICs) of the latex and compounds isolated from Aloe trigonantha

\begin{tabular}{|c|c|c|c|c|c|c|c|c|c|c|c|}
\hline \multirow[t]{2}{*}{ Microorganism } & \multirow[b]{2}{*}{ Latexi } & \multicolumn{5}{|c|}{ Zones of inhibition in $\mathrm{mm}(200 \mathrm{\mu g} / \mathrm{mL})$} & \multirow[b]{2}{*}{ Latex } & \multicolumn{4}{|c|}{$\operatorname{MIC}(\mu \mathrm{g} / \mathrm{mL})^{\mathrm{i}}$} \\
\hline & & $1^{i i}$ & $2^{\mathrm{ii}}$ & 3 ii & $4^{\mathrm{ii}}$ & Cipro & & 1 & 2 & 3 & 4 \\
\hline Bacillus pumilus 82 & $6.0 \pm 0.0$ & $6.0 \pm 0.0^{a}$ & $6.0 \pm 0.0^{a}$ & $10.0 \pm 0.5^{b}$ & $6.0 \pm 0.0^{a}$ & $19.0 \pm 1.3$ & - & - & - & 200 & - \\
\hline B. subtilis ATCC 6633 & $6.0 \pm 0.0$ & $6.0 \pm 0.0^{\mathrm{a}}$ & $6.0 \pm 0.0^{\mathrm{a}}$ & $10.0 \pm 0.6^{b}$ & $6.0 \pm 0.0^{\mathrm{a}}$ & $18.0 \pm 0.7$ & - & - & - & 200 & - \\
\hline Escherichia coli 3:37C & $15.0 \pm 0.9$ & $15.0 \pm 1.2^{\mathrm{a}}$ & $15.0 \pm 0.9^{\mathrm{a}}$ & $14.5 \pm 0.5^{\mathrm{a}}$ & $15.0 \pm 0.7^{\mathrm{a}}$ & $16.5 \pm 0.8$ & 50 & 25 & 25 & 10 & 25 \\
\hline E. coli 872 & $15.0 \pm 0.7$ & $14.5 \pm 0.9^{a}$ & $14.5 \pm 0.6^{\mathrm{a}}$ & $14.5 \pm 0.4^{\mathrm{a}}$ & $14.5 \pm 1.2^{\mathrm{a}}$ & $16.0 \pm 0.9$ & 50 & 25 & 25 & 10 & 25 \\
\hline E. coli CD/99/1 & $15.0 \pm 0.8$ & $15.0 \pm 0.7^{a}$ & $15.0 \pm 0.8^{a}$ & $15.5 \pm 0.9^{a}$ & $15.0 \pm 0.9^{a}$ & $17.0 \pm 1.4$ & 50 & 25 & 25 & 10 & 25 \\
\hline E. coli K88 & $16.5 \pm 1.1$ & $15.5 \pm 0.5^{b}$ & $15.5 \pm 1.2^{b}$ & $15.0 \pm 1.0^{b}$ & $15.5 \pm 0.9^{b}$ & $17.0 \pm 0.5$ & 50 & 50 & 25 & 10 & 25 \\
\hline E. coli LT37 & $15.5 \pm 0.6$ & $14.5 \pm 0.4^{b}$ & $14.5 \pm 1.1^{\mathrm{b}}$ & $14.5 \pm 1.0^{\mathrm{b}}$ & $14.5 \pm 0.5^{b}$ & $16.0 \pm 0.8$ & 50 & 25 & 25 & 10 & 25 \\
\hline E. coli NCTC 5933 & $15.5 \pm 1.2$ & $15.0 \pm 0.9^{a}$ & $14.5 \pm 0.9^{b}$ & $14.5 \pm 0.5^{b}$ & $15.0 \pm 0.8^{\mathrm{a}}$ & $16.0 \pm 0.6$ & 50 & 50 & 50 & 10 & 25 \\
\hline E. coli NCTC 7360 & $16.5 \pm 1.0$ & $15.5 \pm 1.1^{b}$ & $14.5 \pm 0.6^{b}$ & $14.5 \pm 0.7^{b}$ & $15.5 \pm 0.7^{b}$ & $17.0 \pm 1.3$ & 50 & 50 & 50 & 10 & 25 \\
\hline E. coli ROW 7/12 & $15.5 \pm 0.7$ & $15.0 \pm 0.9^{\mathrm{a}}$ & $15.0 \pm 0.5^{a}$ & $14.5 \pm 0.2^{a}$ & $15.0 \pm 0.6^{a}$ & $16.5 \pm 0.4$ & 50 & 25 & 25 & 10 & 25 \\
\hline Salmonella enterica TD 01 & $16.5 \pm 0.9$ & $15.0 \pm 0.6^{b}$ & $13.5 \pm 0.8^{b}$ & $12.5 \pm 0.5^{b}$ & $16.0 \pm 1.2^{\mathrm{a}}$ & $19.0 \pm 0.9$ & 50 & 50 & 100 & 50 & 25 \\
\hline S. typhi Ty2 & $15.0 \pm 1.2$ & $15.0 \pm 0.8^{\mathrm{a}}$ & $14.0 \pm 0.7^{b}$ & $14.0 \pm 0.6^{b}$ & $15.0 \pm 0.9^{a}$ & $16.0 \pm 0.5$ & 50 & 25 & 50 & 10 & 25 \\
\hline Shigella boydii D 13629 & $15.0 \pm 0.5$ & $15.5 \pm 0.8^{a}$ & $14.5 \pm 0.9^{a}$ & $16.5 \pm 0.4^{a}$ & $15.5 \pm 0.6^{\mathrm{a}}$ & $20.0 \pm 0.7$ & 50 & 50 & 50 & 10 & 50 \\
\hline S. dysentery 8 & $14.5 \pm 0.8$ & $14.0 \pm 0.7^{\mathrm{a}}$ & $13.5 \pm 0.9^{b}$ & $15.5 \pm 0.6^{b}$ & $13.5 \pm 0.4^{b}$ & $20.0 \pm 0.8$ & 50 & 25 & 50 & 10 & 50 \\
\hline S. flexneri Type 6 & $15.0 \pm 0.7$ & $15.5 \pm 0.5^{\mathrm{a}}$ & $15.5 \pm 0.6^{\mathrm{a}}$ & $15.5 \pm 0.5^{\mathrm{a}}$ & $15.5 \pm 0.7^{\mathrm{a}}$ & $20.5 \pm 0.7$ & 50 & 50 & 50 & 10 & 50 \\
\hline S. soneii 1 & $15.0 \pm 0.5$ & $15.5 \pm 0.9^{\mathrm{a}}$ & $15.5 \pm 0.8^{\mathrm{a}}$ & $15.5 \pm 0.5^{\mathrm{a}}$ & $15.5 \pm 0.6^{a}$ & $19.5 \pm 1.2$ & 50 & 100 & 50 & 10 & 50 \\
\hline Staphylococcus aureus ML 267 & $14.5 \pm 0.9$ & $14.5 \pm 1.3^{\mathrm{a}}$ & $14.5 \pm 0.5^{\mathrm{a}}$ & $14.5 \pm 0.6^{\mathrm{a}}$ & $13.5 \pm 0.9^{b}$ & $18.0 \pm 1.4$ & 100 & 50 & 100 & 25 & 100 \\
\hline Vibrio cholerae NCTC 10732 & $14.0 \pm 0.4$ & $15.5 \pm 0.8^{b}$ & $15.0 \pm 1.1^{b}$ & $14.5 \pm 1.0^{\mathrm{b}}$ & $15.5 \pm 0.9^{b}$ & $19.0 \pm 0.9$ & 50 & 25 & 25 & 10 & 25 \\
\hline V. cholerae NCTC 11501 & $14.5 \pm 0.6$ & $15.5 \pm 0.4^{b}$ & $14.0 \pm 0.7^{\mathrm{a}}$ & $15.0 \pm 0.3^{a}$ & $15.5 \pm 0.7^{b}$ & $18.5 \pm 0.8$ & 50 & 25 & 25 & 10 & 25 \\
\hline V. cholerae NCTC 4693 & $13.5 \pm 0.8$ & $14.5 \pm 0.9^{b}$ & $15.0 \pm 0.8^{b}$ & $15.0 \pm 0.3^{b}$ & $14.5 \pm 0.9^{b}$ & $17.5 \pm 0.5$ & 50 & 25 & 25 & 10 & 25 \\
\hline V. cholerae NCTC 5596 & $14.0 \pm 0.3$ & $15.0 \pm 0.7^{b}$ & $15.0 \pm 0.7^{b}$ & $15.0 \pm 0.5^{b}$ & $15.0 \pm 0.5^{b}$ & $18.5 \pm 0.8$ & 50 & 25 & 25 & 10 & 25 \\
\hline Fungal strains & Latexi & $1^{\mathrm{ii}}$ & $2^{i i}$ & $3^{\mathrm{ii}}$ & $4^{i i}$ & Gris. & Latex & 1 & 2 & 3 & 4 \\
\hline Aspergillus niger ATCC 6275 & $9.0 \pm 0.7$ & $11.0 \pm 1.3^{b}$ & $12.0 \pm 0.9^{b}$ & $12.5 \pm 0.6^{b}$ & $12.5 \pm 0.9^{b}$ & $15.0 \pm 0.9$ & 1500 & 1000 & 1000 & 800 & 1000 \\
\hline Candida albicans ATCC 10231 & $10.0 \pm 0.9$ & $10.0 \pm 0.8^{\mathrm{a}}$ & $14.0 \pm 1.2^{b}$ & $13.5 \pm 1.0^{b}$ & $14.5 \pm 0.8^{b}$ & $16.0 \pm 1.3$ & 800 & 400 & 400 & 800 & 400 \\
\hline Penicillium funiculosum NCTC 287 & $8.0 \pm 0.6$ & $9.5 \pm 0.5^{\mathrm{a}}$ & $12.5 \pm 0.7^{b}$ & $12.0 \pm 0.4^{b}$ & $13.5 \pm 0.5^{b}$ & $13.5 \pm 1.1$ & 1000 & 800 & 800 & 800 & 400 \\
\hline P. notatum ATCC 11625 & $8.0 \pm 0.8$ & $10.0 \pm 0.7^{b}$ & $12.5 \pm 0.6^{b}$ & $12.0 \pm 0.5^{b}$ & $12.5 \pm 0.4^{b}$ & $13.5 \pm 0.9$ & 1000 & 800 & 800 & 800 & 400 \\
\hline
\end{tabular}

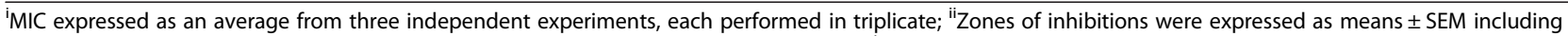
the $6 \mathrm{~mm}$ diameter of the disc; ${ }^{a}: p>0.05$ when compared to the latex on the same row; ${ }^{b}: p<0.05$ when compared to the latex on the same row; 1 : Aloesin, 2: 8-O-Methyl-7-hydroxyaloin A/B, 3: Aloin A/B; 4: Aloin-6'-O-acetate A/B; Cipro: Ciprofloxacin; Gris: Griseofulvin

phospholipids and perturbations of the core of the phospholipid bilayer.

\section{Antifungal activity}

The fungi tested in the present study were shown to have limited susceptibility to both the latex and its components although zones of inhibition displayed by the latex were somewhat smaller than those obtained for the isolated compounds. Among the fungal strains tested, $C$. albicans was found to be more susceptible (MIC $=400-$ $800 \mu \mathrm{g} / \mathrm{mL}$ ) to the test compounds than the other fungal pathogens, which exhibited different levels of sensitivity. Previous studies in our laboratory have found the anthrones aloin and 7-O-methylaloeresin isolated from the leaf latex of $A$. harlana to be capable of inhibiting the growth of C. albicans, Penicillium funiculosum and
P. notatum to a similar extent observed in the present study [11]. Moreover, aloin from A. ferox, emodin and barbaloin from Rheum australe were shown to inhibit the growth of C. albicans [34] and a range of pathogenic fungal strains [35], respectively.

\section{Conclusions}

The findings of the present study have established the susceptibilities of a broad range of bacteria particularly Gram-negative pathogens to the latex of $A$. trichosantha and its components. The Gram-positive strains tested were either not inhibited by or showed limited susceptibility to any of the tested substances. The inhibitory effects of the isolated compounds against various pathogenic microorganisms had clearly demonstrated the usefulness of A. trichosantha in the treatment of various diseases caused 
by these pathogenic strains and explains, in part or in whole, the use of the plant in traditional medicine. Furthermore, the identification of such natural antimicrobial compounds may lead to the development of novel antimicrobials through structure/activity studies.

\section{Competing interests}

The authors declare that they have no competing interests.

\section{Authors' contributions}

MM: Collected plant material, carried out the experimental work and drafted the manuscript. DB: Assisted in the extraction, isolation, preparation and identification of compounds including interpretation of spectral data. AM: Designed and carried out experiments for in vitro antimicrobial activity testing. KA: Involved in the isolation and preparation of compounds, corrected, edited and proof read the manuscript before submission. All authors read and approved the final manuscript.

\section{Acknowledgement}

The authors are thankful to Prof Sebsebe Demissew, the National Herbarium, Addis Ababa University for identification of the plant material.

\section{Author details}

${ }^{1}$ Department of Pharmaceutical Chemistry and Pharmacognosy, School of pharmacy, College of Health Sciences, Addis Ababa University, Addis Ababa, Ethiopia. ${ }^{2}$ Department of Pharmaceutical Technology, Noida Institute of Engineering and Technology, 19 Knowledge Park II, Institutional Area, Greater Noida 201306, India.

\section{Received: 16 March 2015 Accepted: 5 August 2015}

Published online: 12 August 2015

\section{References}

1. Khalil A, Dababneh BF, Al-Gabbiesh AH. Antimicrobial activity against pathogenic microorganisms by extracts from herbal Jordanian plants. J Food Agric Env. 2009;7:103-6.

2. Silva NC, Fernandes JA. Biological properties of medicinal plants: a review of their antimicrobial activity. J Venom Anim Toxins. 2010;16:402-13.

3. Mahady GB. Medicinal plants for the prevention and treatment of bacterial infections. Curr Pharm Des. 2005:11:2405-27.

4. WHO: Antimicrobial Resistance: Global Report on Surveillance. Geneva; Switherland. 2014

5. Mahesh B, Satish S. Antimicrobial activity of some important medicinal plants against plant and human pathogens. World J Agric Sci. 2008:4:839-43.

6. Nielsen TRH, Kuete V, Jager AK, Meyer JJM, Lall N. Antimicrobial activity of selected South African medicinal plants. BMC Complement Altern Med. 2012;12:74.

7. Vashist $H$, Jindal A. Antimicrobial activities of medicinal plants -Review Int J Res Pharm Biomed Sci. 2012;3:222-30.

8. Kawai K, Beppu H, Koike T, Fujita K, Marunouchi T. Tissue culture of Aloe arborescens Miller var. natalensis Berger. Phytother Res. 1993;7:5-10.

9. University of California Davis Botanical Conservatory (UCDAVIS). The genus Aloe Botanical Notes. 2009:1:1-11

10. Demissew S, Nordal I. Aloes and Lilies of Ethiopia and Eritrea. Addis Ababa: Shama Books; 2003.

11. Asamenew G, Bisrat D, Mazumder A, Asres K. In vitro antimicrobial and antioxidant activities of anthrone and chromone from the latex of Aloe harlana Reynolds. Phytother Res. 2011;25:1756-60.

12. Minale G, Bisrat D, Asres K, Mazumder A. In vitro antimicrobial activities of anthrones from the leaf latex of Aloe sinana Reynolds. Int J Green Pharm. 2014;8:7-12

13. Gemechu W, Bisrat D, Asres K. Antimalarial anthrone and chromone from the leaf Latex of Aloe debrana Chrstian. Ethiop Pharm J. 2014;30:1-9.

14. ELhassan GOM, Adhikari A, Yousuf S, Rahman H, Khalid A, Omer H, et al. Phytochemistry and antiglycation activity of Aloe sinkatana Reynolds. Phytochem Lett. 2012;5:725-8.

15. Belayneh A, Bussa NF. Ethnomedicinal plants used to treat human ailments in the prehistoric place of Harla and Dengego valleys, eastern Ethiopia. J Ethnobiol Ethnomed. 2014;10:18.
16. Bekele D, Asfaw Z, Petros B, Tekie H. Ethnobotanical study of plants used for protection against insect bite and for the treatment of livestock health problems in rural areas of Akaki District, Eastern Shewa, Ethiopia. Top Class J Herbal Med. 2012;1:40-52.

17. Megeressa M. Antimalarial and Antimicrobial Activities of Anthrones and Chromone from the Leaf Latex of Aloe trigonantha, M.Sc. Thesis. Addis Ababa: Addis Ababa University; 2013.

18. Mitchell JK, Carter WE. Modeling antimicrobial activity of Clorox ${ }^{\mathrm{TM}}$ using an agar-diffusion test: a new twist on an old experiment. Biosci. 2000;26:9-13.

19. Hecht DW, Citron DM, Cox M, Jacobus N, Jenkins SG, Onderdonk A, et al. Methods for dilution antimicrobial susceptibility tests for bacteria that grow aerobically; approved standard - sixth edition. NCCLS (National Committee for Clinical Laboratory Standards). 2003;27(2):19087-1898.

20. Dagne E, Bisrat D, Viljoen A, Van Wyk B-E. Chemistry of Aloe species. Curr Org Chem. 2000;4:1055-78.

21. Speranza G, Gramatica P, Dada G, Manitto P. Aloeresin C: a bitter C,O-diglucoside from Cape Aloe. Phytochemistry. 1985;24:1571-3.

22. Conner JM, Gray Al, Reynolds T, Waterman PG. Anthrone and chromone components of Aloe cremnophila and Aloe jacksoni leaf exudates. Phytochemistry. 1990;29:941-4.

23. Oumer A, Bisrat D, Mazumder A, Asres K. A new antimicrobial anthrone from the leaf latex of Aloe trichosantha. Nat Prod Commun. 2014:9:949-52.

24. Mariappan V, Shanthi G. Antimicrobial and phytochemical analysis of Aloe vera $\mathrm{L}$. Int Res J Pharm. 2012;3:158-61.

25. Gatsing D, Djemgou PC, Garba IH, Aliyu R, Tchuendem MH, Tane P, et al. Dihydronaphtalenone and chromone from Cassia petersiana Bolle and the antisalmonellal activity of its crude extract. Res J Phytochem. 2007;1:40-5.

26. Al-Yahya M, Muhammad I, Mirza HH, El-Feraly FS. Antibacterial constituents from the rhizomes of Ferula communis. Phytother Res. 1998;12:335-9.

27. Cock IE. Antimicrobial activity of Aloe barbadensis Miller leaf gel components. Internet J Microbiol. 2007;4:2.

28. Budzisz E, Nawrot E, Malecka M. Synthesis, antimicrobial, and alkylating properties of 3-phosphonic derivatives of chromone. Arch Pharm Med Chem. 2001;334:381-7

29. Wu YW, Ouyang J, Xiao XH, Gao WY, Liu Y. Antimicrobial properties and toxicity of anthraquinones by microcalorimetric bioassay. Chinese J Chem. 2006:24:45-50.

30. Xiang W, Song Q-S, Zhang H-J, Guo SP. Antimicrobial anthraquinones from Morinda angustifolia. Fitoterapia. 2008;79:501-4.

31. Hamman JH. Composition and applications of Aloe vera leaf gel. Molecules. 2008;13:1599-616.

32. Ubbink-Kok T, Anderson JA, Konings WN. Inhibition of electron transfer and uncoupling effects by emodin and emodinanthrone in Escherichia coli. Antimicrob Agents Chemother. 1986;30:147-51.

33. Alves DS, Pérez-Fons L, Estepa A, Micol V. Membrane-related effects underlying the biological activity of the anthraquinones emodin and barbaloin. Biochem Pharmacol. 2004;68:549-61.

34. Kambizi L, Afolayan AJ. Extracts from Aloe ferox and Withania somnifera inhibit Candida albicans and Neisseria gonorrhea. Afr J Biotechnol. 2008;7:12-5.

35. Rokaya MB, Munzbergova Z, Timsina B, Bhattarai KR. Rheum australe D. Don: a review of its botany, ethnobotany, phytochemistry and pharmacology. J Ethnopharmacol. 2012;141:761-74.

\section{Submit your next manuscript to BioMed Central and take full advantage of:}

- Convenient online submission

- Thorough peer review

- No space constraints or color figure charges

- Immediate publication on acceptance

- Inclusion in PubMed, CAS, Scopus and Google Scholar

- Research which is freely available for redistribution 